\title{
The Implementation of Marine Cadastre in Indonesia (Case Study : Maratua Island, East Kalimantan)
}

\author{
Resti Yully Astutia,*, Yanto Budisusanto ${ }^{b}$, Danar Guruh Pratomo \\ Department of Geomatics Engineering, Institut Teknologi Sepuluh Nopember, Surabaya, Indonesia \\ a.restiyully18@gmail.com,b.yantobudisusanto@gmail.com,c.guruh@geodesy.its.ac.id \\ *corresponding author
}

Keywords: $\quad$ Floating Net Cages, Maratua, Marine Cadastre, Marine Space, Zoning Plan.

Abstract: Indonesia is one of the largest archipelagic countries in the world which has more than 17,000 islands. Approximately 2.9 million $\mathrm{km} 2$ of waters covers the country. An authority to regulate the marine area is required in order to manage it. However, the policy and the institutional framework to govern the utilization of the marine space are still complicated. Legal and technical aspects need to be examined for utilizing it. The Zoning Plan which determines the direction of the marine resource utilization accompanied by the spatial structures establishment and the pattern of activities in the planning area should be consider before the government issues the permit for utilization.

The purpose of this research is to analyse the suitability of Coastal Areas and Small Islands Zoning Plans (RZWP3K) against current marine space utilization on Maratua Island which is one of the outermost small islands enclosed in Indonesian's Law No. 1 of 2014 on Management of Coastal Areas and Small Islands. This constitution includes the management of marine parcel as a part of the marine cadastre implementation. The research investigates the marine space utilization, and analyses the suitability between the zoning plan and the existing condition. The research also compiles the marine parcel based on the zoning plan data using a Geographic Information System.

Based on this research, there are 7 zoning plan of marine space utilization, 9 sub zones and 6 existing areas of Floating Net Cages (FNC) in Maratua Island. There are 3 areas of FNC that overlap with sub-zones of ecotourism and ecosystem protection. The FNC area which does not affirm with the zoning plan is $27 \%$ of the total FNC area. The regulation for the maximum area of marine parcel in FNC sub-zone plan is $50,000 \mathrm{~m} 2$ therefore 600 marine parcels are arranged in this area.

\section{Introduction}

Indonesia has approximately 17,504 islands. This makes the country as one of the largest archipelagic countries in the world. Approximately 1,910,931 $\mathrm{km}^{2}$ of lands covers the country [1]. According to Ministry of Marine Affairs and Fisheries Republic of Indonesia 2011, Indonesia has 
approximately $284,210.900 \mathrm{~km}^{2}$ of territorial marine space and the area of Exclusive Economic Zone (EEZ) is 2,981,211.000 $\mathrm{km}^{2}$. Based on this marine space, an effective regulation is required in order to manage the economic, social, and environment needs. An authority to regulate the marine space is required in order to manage it. However, the policy and the institutional framework to govern the utilization of the marine space are still complicated. In UNCLOS juncto UU No. 17, 1985 explains that marine space can be separated into parcels for exploitation and utilization [2]. For examples are economical business space such as fish farming, seaweed, shell, and seabed mining; sea space for conservation of marine protected and a national park; public space such as navigation, port, and so on [3].

The purpose of this research is to analyse the suitability of Coastal Areas and Small Islands Zoning Plans against current marine space utilization based on UU No. 1, 2014. This research location is on Maratua Island which is one of the 111 islands in the outermost small islands specified in Presidential Decree No. 6, 2017 [4]. This island has the zoning plan of marine space utilization. Article 1 Section 1 of UU No. 1, 2014 explains that coastal area and small islands management is utilization, supervision, and control of coastal resources and small islands by government, intersectoral, between terrestrial and marine ecosystems, and between science and management to prosperity development [5].

The Zoning Plan which determines the direction of the marine resource utilization accompanied by the spatial structures establishment and the pattern of activities in the planning area should be considered before the government issues the permit for utilization [6]. The planning zone of Coastal Areas and Small Islands Zoning Plans enclosed in Article 18 consists of terrestrial areas covering the administrative areas of the subdistrict and to the marine space which is 12 miles away from the baseline of the archipelago or as stated in the law. For marine space up to 2 miles is preferred to be utilized as a conservation area, livelihood area, and access for fisherman, small fish farmers, and small salt farmers, sustainable marine tourism, and public infrastructure.

\section{Research Methodology}

\subsection{Research Area}

The research area is located in Maratua Island, Maratua Sub district, Berau District, East Kalimantan. The geographical coordinates of this area is $2^{\circ} 11^{\prime} 27^{\prime \prime} \mathrm{N}-118^{\circ} 36^{\prime} 26^{\prime \prime} \mathrm{E}$. This area was selected because Maratua Island is one of the outermost small islands enclosed in Indonesian and pilot project of marine cadaster implementation.

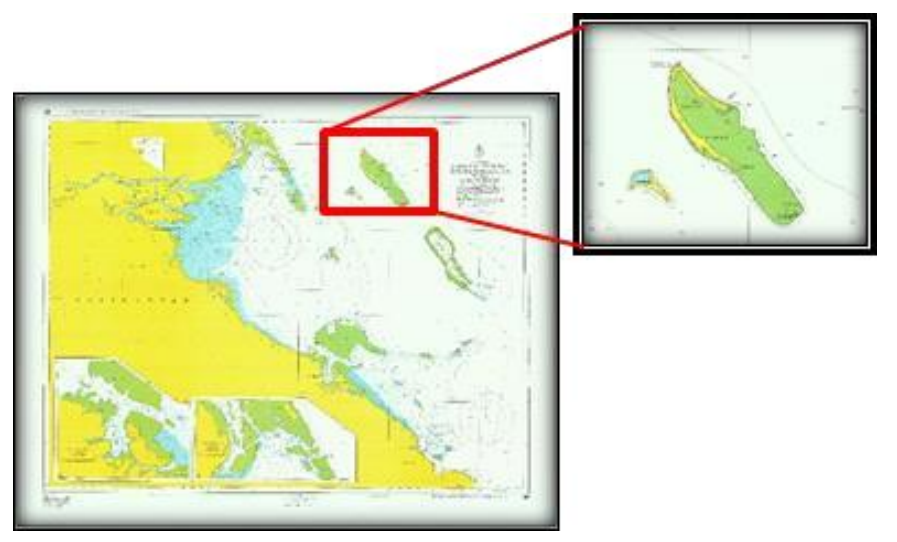

Fig. 1. Research Area 


\subsection{Data and Tool Acquisition}

Data required in this research are from the Ministry of Marine Affairs and Fisheries Republic of Indonesia, which consists of Coastal Areas and Small Islands Zoning Plans Maratua Island 2016, this data covers a lot of important data in egards of zoning plan, while the data of Coastal Areas and Small Islands Zoning Plans that are used in this research are bathymetry data and the allocation of marine area utilization saved in shapefile format (.shp). The second data used is the existing data of Maratua Island 2016, which includes the area and location or coordinate of Floating Net Cages which currently exists on the sea of Maratua Island.

In this research, ArcGIS 10.3 software is used for maps processing and data analysis. Other than that, the software is also used on the stage of suitability analysis of the existing marine area utilization on behalf of Coastal Areas and Small Islands Zoning Plans. Sketch Up 10 is used to create 3D model on the utilization sample of marine space vertically.

\subsection{Methods}

\subsubsection{Inventorization of Maratua Islands Marine Space Potential}

Inventorization of marine spatial potentials is conducted on the Maratua Island RZWP3K map to find out the various planned marine spaces utilization in Maratua Island and the area of each marine space utilization zone.

\subsubsection{Inventorization of Existing FNC}

Inventorization of FNC cultivation is conducted on existing map data of marine space utilization on Maratua Island. This inventorization aims to determine the location or coordinates of each FNC that already exist in the waters of Maratua Island and know the size of each FNC.

\subsubsection{Overlay of Plan and Existing Data}

Based on Coastal Areas and Small Islands Zoning Plans Map is to find out the utilization of marine space on Maratua Island and the areas of zone of marine space utilization. The data should be overlaid with Floating Net Cages (FNC) Cultivation on existing map to find the location or coordinate of FNC on Maratua Island and to find out the areas of it.

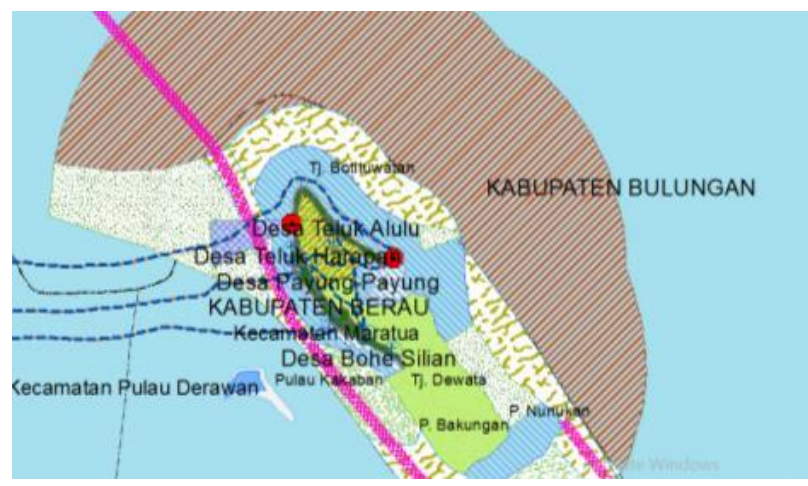

Fig. 2. Overlay Coastal Areas and Small Islands Zoning Plans Data with Existing Data

\subsubsection{Analysis of Marine space Utilization Suitability}

The analysis of marine space suitability is obtained from attribute table data on the overlay result and from UU No. 1, 2014. Thus, there are some areas of marine space utilization that are 
unsuitable with zoning plan of marine space. It is also based on UU No. 1, 2014 which is reviewed from the granting of location permits. In accordance with article 16, every spatial utilization of some coastal waters and small islands settled must have location permit with a certain time and area. However, location permits cannot be granted for all areas because there are some zone that are not allowed to be used by individuals or groups.

\subsubsection{The Establishment of Marine Parcel}

The establishment of marine parcel is conducted by Gridding method using Fishnet function. Gridding process is done by dividing the zone of cultivation fishery into 50,000 $\mathrm{m} 2$ sized parcels.

\section{Result and Discussion}

\subsection{Identifications of Marine space Utilization on Maratua Island}

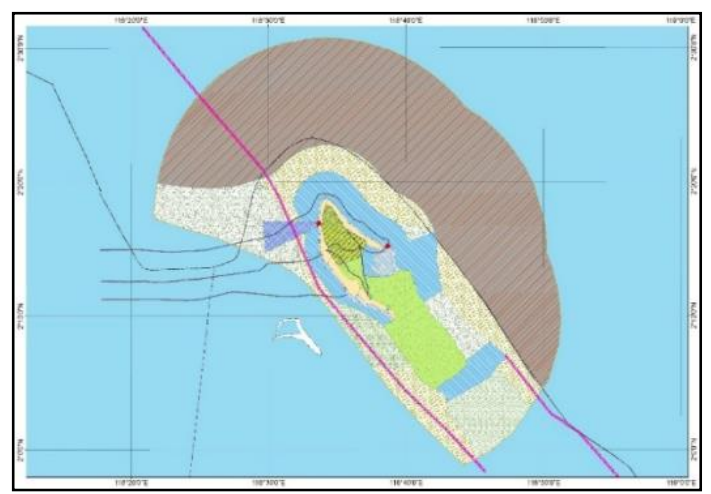

Fig. 3. Map of Inventory of Marine Space Potential on Maratua Islan

This Coastal Areas and Small Islands Zoning Plans location is on 12 miles away from the coastline. From the map it can be seen that according to Coastal Areas and Small Islands Zoning Plans which has been planned by the government especially Ministry of Marine Affairs and Fisheries Republic of Indonesia that Maratua used for some activities that can be seen in the descriptions below.

Table 1. Inventory of Marine space Utilization on Maratua Island

\begin{tabular}{|c|c|c|c|}
\hline Zone & Symbol & Subzone & Area $\left(\mathbf{m}^{2}\right)$ \\
\hline Cultivation Fishery & & Cultivation of FNC & $26,568,410$ \\
\hline \multirow[t]{2}{*}{ Zone of Fishing } & & Sub Zone of Pelagic Fishing & $971,806,040$ \\
\hline & & Sub Zone of Demersal Fishing & $73,054,170$ \\
\hline \multirow[t]{2}{*}{ Core Zone } & & Ecosystem Protection & $110,545,190$ \\
\hline & & Protection of Migratory Lanes of Marine Biota & $251,108,760$ \\
\hline Other Zone & & Sub Zone of Region Protection & $44,792,690$ \\
\hline Zone of Port & & Sub Zone of WKOPP & $18,602,110$ \\
\hline \multirow{2}{*}{$\begin{array}{l}\text { Zone of Limited } \\
\text { Utilization }\end{array}$} & 8 in & Zone of Core Zone Buffer & $161,541,660$ \\
\hline & NWW & Sub Zone of Eco-tourism & $186,083,779$ \\
\hline
\end{tabular}




\subsection{Results of Recapitulation Area of Existing FNC}

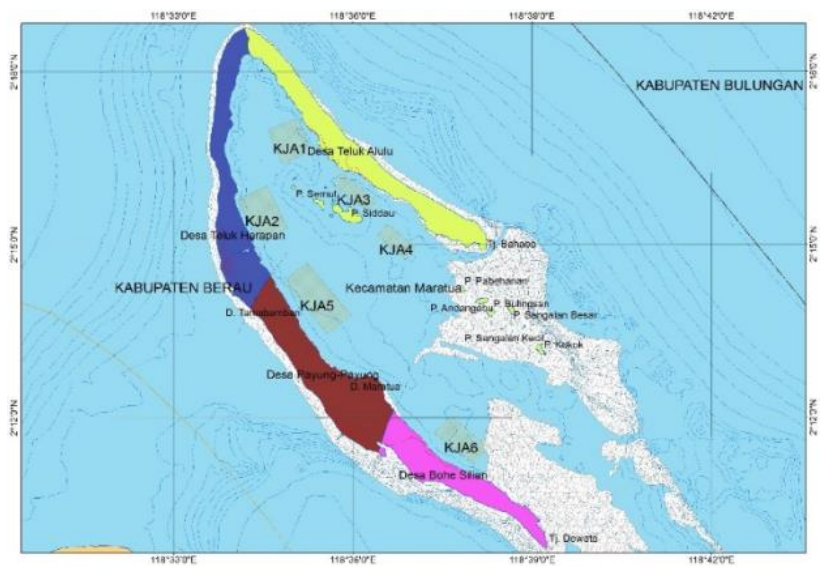

Fig. 4. Map of Utilization of Existing Marine Space

Based on the map above, FNC existing with six of FNC is described in Table 2 as below:

Table 2. Fish Cultivation Data of Existing FNC

\begin{tabular}{|c|c|c|c|}
\hline Code & Latitude $\left({ }^{\circ} \mathbf{N}\right)$ & Longitude $\left({ }^{\circ} \mathbf{E}\right)$ & Area $\left(\mathbf{m}^{\mathbf{2}}\right)$ \\
\hline KJA1 & 2.279998 & 118.58246 & $1,149,270$ \\
\hline KJA2 & 2.258985 & 118.57474 & $1,492,750$ \\
\hline KJA3 & 2.265143 & 118.60028 & 642,660 \\
\hline KJA4 & 2.250719 & 118.6121 & 604,720 \\
\hline KJA5 & 2.23448 & 118.59003 & $2,025,040$ \\
\hline KJA6 & 2.193495 & 118.6302 & 1139310 \\
\hline
\end{tabular}

\subsection{Results of Recapitulation Area of Unsuitable FNC}

From the results of the analysis, there are some zones that are unsuitable with the zoning plan. It is described in Table 3 as follows:

Table 3. Suitability of Existing into Spatial Plan

\begin{tabular}{|c|c|c|}
\hline Code & Suitable Area $\left(\mathbf{m}^{\mathbf{2}}\right)$ & Unsuitable Area $\left.\mathbf{( m}^{\mathbf{2}}\right)$ \\
\hline KJA1 & $1,149,270$ & 0 \\
\hline KJA2 & $1,492,750$ & 0 \\
\hline KJA3 & 642,660 & 0 \\
\hline KJA4 & 545,430 & 5,929 \\
\hline KJA5 & $1,311,040$ & 714,000 \\
\hline KJA6 & 0 & $1,139,310$ \\
\hline
\end{tabular}

Percentage of suitability test of existing into Coastal Areas and Small Islands Zoning Plans on Maratua Island is described in figure below: 


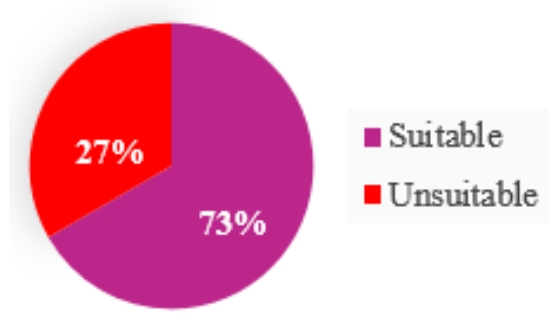

Fig. 5. Graph of Percentage of Existing into Zoning Plans Suitability

From the graph above, it can be seen that the area of FNC in the suitable zone is 5,141,150 $\mathrm{m} 2$ or about $73 \%$ and the unsuitable area is $1,912,600 \mathrm{~m} 2$ or about $27 \%$ of the total existing FNC is $7,053,750 \mathrm{~m} 2$.

\subsection{Map of Existing into Coastal Areas and Small Islands Zoning Plans Suitability}

In this research, overlay Coastal Areas and Small Islands Zoning Plans with existing data of FNC results a map which is shown in the picture below.

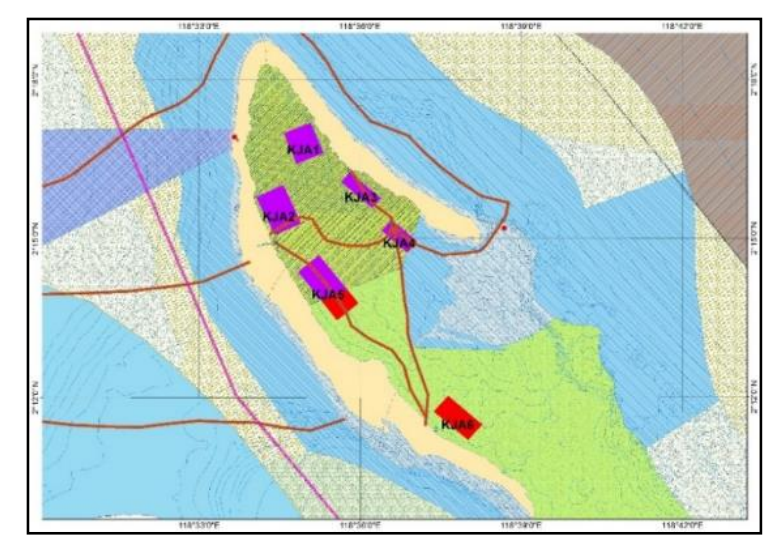

Fig. 6. Map of Suitability of the Zoning Plan and Existing FNC

This map describes that there are some areas which are unsuitable. The overlapping areas will be explained in the table below:

Table 4. Suitability Identification of The Zoning Plan and Existing of FNC on Maratua

\begin{tabular}{|c|c|c|c|}
\hline \multirow{2}{*}{ Code } & \multicolumn{3}{|c|}{ Spatial Use in RZ } \\
\hline & Cultivation of FNC & Eco-tourism & Ecosystem Protection \\
\hline KJA1 & $\checkmark$ & & \\
\hline KJA2 & $\checkmark$ & & \\
\hline KJA3 & $\checkmark$ & & \\
\hline KJA4 & $\checkmark$ & $\checkmark$ & $\checkmark$ \\
\hline KJA5 & $\checkmark$ & & $\checkmark$ \\
\hline KJA6 & & & \\
\hline
\end{tabular}


Table 5. Unsuitable FNC Data

\begin{tabular}{|r|r|r|l|}
\hline \multicolumn{1}{|c|}{ No } & Latitude $\left({ }^{\circ} \mathbf{N}\right)$ & Longitude $\left({ }^{\circ} \mathbf{E}\right)$ & \multicolumn{1}{c|}{ Overlapping Areas } \\
\hline 1 & 2.279 & 118.582 & FNC in eco-tourism sub zone \\
\hline 2 & 2.258 & 118.574 & FNC in sub zone ecosystem protection \\
\hline 3 & 2.265 & 118.600 & FNC in sub zone ecosystem protection \\
\hline
\end{tabular}

\subsection{Marine Parcel}

According to the draft regulation of the minister of marine and fisheries concerning the location permit on Article 14 that every person has the right to apply the location permit for the cultivation fishery with maximum area is $50,000 \mathrm{~m} 2$ and for the corporation can apply permit with maximum area 2,000,000 $\mathrm{m} 2$. After gridding the cultivation fishery zone using fishnet method obtained as many as 600 pieces of marine parcel consisting of 471 plots with an area of 50,000 m2 and 109 marine parcels with an area less than 50,000 $\mathrm{m} 2$. So, the marine parcel map can be used as a reference for the granting of location permit with maximum distribution of one plot for individual and forty plots for the company.

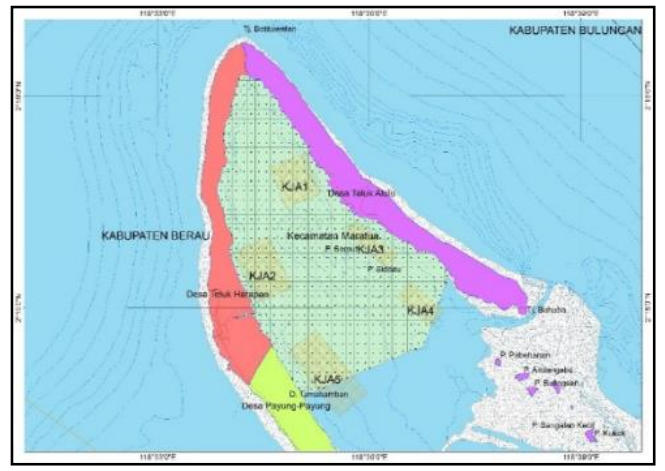

Fig. 7. Map of Marine Parcel

\section{Conclusion}

The conclusions of this research are:

- Total of Floating Net Cages (FNC) based on existing map data on Maratua Island in 2016 is 6 FNC with total area of $7,053,750 \mathrm{~m}^{2}$. While the area of the zoning plan of FNC cultivation on Coastal Areas and Small Islands Zoning Plans Maratua Island is 26,568,410 $\mathrm{m}^{2}$.

- Out of 6 FNC, there are 3 FNC that are unsuitable with the zoning plan which consist of 2 FNC whose part of its territory is outside the cultivation zone and $1 \mathrm{FNC}$ which is entirely outside the cultivation zone. Unsuitable FNC with the zoning plan is located in the sub zone of ecosystem protection and sub zone of eco-tourism.

- The area of existing FNC that is suitable to Coastal Areas and Small Islands Zoning Plans is $5,141,150 \mathrm{~m}^{2}$ or about $73 \%$ and the rest (the unsuitable area) is $1,912,600 \mathrm{~m}^{2}$ or about $27 \%$ of the total area.

- The marine parcels are established in FNC cultivation zoning plan with total of 600 pieces of parcel. Thus marine parcels consist of 471 plots with area of 50,000 $\mathrm{m}^{2}$ and 109 marine parcels with area less than $50,000 \mathrm{~m}^{2}$.

The recommendation from this research is the existing location of FNC is important in preparation of Coastal Areas and Small Islands Zoning Plans. So that the zoning plan of FNC cultivation is 
suitable with existing condition of FNC. New FNC must also suitable with the location of Coastal Areas and Small Islands Zoning Plans. In order the marine space utilization suitable the zoning plan, it is necessary to have a location permit granted by the government to individuals or groups that will take advantage of the marine space.

\section{Acknowledgment}

The authors give thanks to Yanto Budisusanto, ST., M.Eng. and Danar Guruh Pratomo, ST., MT., $\mathrm{Ph} . \mathrm{D}$. who have given assistance, and also Ministry of Marine Affairs and Fisheries Republic of Indonesia who has given data.

\section{References}

[1] Badan Pusat Statistik-RI, 2015, Luas Laut Indonesia, www.bps.go.id/linkTabelStatis/view/id/1366 (Accessed on 10/11/2017).

[2] Pemerintah Republik Indonesia. 1985. Undang-Undang Republik Indonesia Nomor 17 Tahun 1985 Tentang Pengesahan United Nations Convention On The Law Of The Sea. Jakarta.

[3] Pemerintah Republik Indonesia, 2014, Undang-Undang Republik Indonesia Nomor 1 Tahun 2014 tentang Perubahan Atas Undang-Undang Nomor 27 Tahun 2007 Tentang Pengelolaan Wilayah Pesisir dan Pulau-Pulau Kecil, Jakarta.

[4] Pemerintah Republik Indonesia. 2017. Keputusan Presiden RI Nomor 6 Tahun 2017 Tentang Penetapan Pulau Pulau Kecil Terluar. Jakarta.

[5] Pemerintah Republik Indonesia. 2014. Undang-Undang Republik Indonesia Nomor 1 Tahun 2014 Tentang Perubahan Atas Undang-Undang Nomor 27 Tahun 2007 Tentang Pengelolaan Wilayah Pesisir dan Pulau-Pulau Kecil. Jakarta.

[6] Rais, Jacub, 2003, “Marine Cadastre” di Indonesia, Suatu Konsep Penataan Ruang Wilayah Laut, Salindia Presentasi CRMP-BPN RI, Jakarta 